\section{JURNAL ABDIMAS

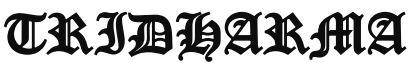

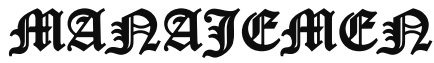

\title{
PENGARAHAN SERTA PENGIMPLEMENTASIAN FUNGSI DAN PENGARUH MEDIA SOSIAL BAGI PERKEMBANGAN BERFIKIR ORANG TUA DAN ANAK
}

\author{
(Studi Kasus Pada Majlis Taklim Al Auladiyah, Bakti Jaya, Setu, Tangerang \\ Selatan)
}

\author{
Tutri Indraswari*, Ananda Hadistia, Ayu Puspa Lestiyadi, Kartika Sari Dewi \\ Dosen Manajemen Fakultas Ekonomi Universitas Pamulang \\ Email* : dosen02446@unpam.ac.id, dosen02397@unpam.ac.id, \\ dosen02505@unpam.ac.id, dosen02506@unpam.ac.id
}

\begin{abstract}
ABSTRAK
Kegiatan Pegabdian Kepada Masyarakat ini bertujuan untuk memberikan pengarahandan pengimplementasian sosial media terhadap perkembangan berfikir orang tua kepada anggota Majlis Taklim. Metode kegiatan yang digunakan adalah bekerjasama dengan Ketua Dewan Kemakmuran Masjid Al Auladiyah, yang beralamat diBakti Jaya, Tangerang Selatan dan memberikan pengarahan serta pengimplementasian tentang bagaimana sosial media sebaiknya digunakan, dampak baik buruknya sosial media dan bagaimana gambaran sosial media dalam kehidupan sehari-hari. Setelah dianalisis maka kami memberikan pengarahan dalam bentuk pemaparan dan tanya jawab yang bertujuan mengembangkan pengetahuan kepada orang tua dalam sosial media. Hasil kegiatan menunjukkan bahwa sebelum pelaksanaan PKM, Ibu-ibu Masjlis Taklim belum mengetahui lebih jelas mengenai sosial media dan bagaimana sosial media seharusnya digunakan, namun setelah pelaksaan kegiatan PKM ini diketahui para orang tua setidaknya sudah mempunyai sedikit bekal dan dapat memahami bagaimana sosial media sebaiknya digunakan dengan seharusnya. Kegiatan PKM berperan positif dalam meningkatkan pengetahuan dan pengharapan akan manfaat sosial media bagi hidup bersosialiasi dan perkembangan berfikir orang tua dan anak
\end{abstract}

\section{Kata Kunci : PKM, Sosial Media , Perkembangan Berfikir, Orang tua dan anak}

\begin{abstract}
This Community Service activity aims to provide direction and implementation of social media on the development of parents' thinking to Majlis Taklim members. The method of activity used is dealing with the Chairperson of the Al Auladiyah Mosque Prosperity Council, which is located in Bakti Jaya, South Tangerang and provides guidance and implementation on how social media is used, enabling social media and social media in everyday life. After completion, we provide an experience in the form of exposure and questions and answers that develop knowledge for parents on social media. The results of the Activity show that prior to the implementation of the PKM, the women of Masjlis Taklim did not know
\end{abstract}




\section{JURNAL ABDIMAS

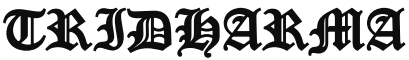

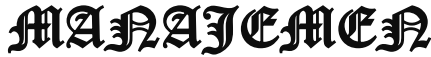

P-ISSN 2615-6849, E-ISSN 2622-3686

Jurnal ABDIMAS Vol. 1,No. 3,September 2020,Hal (95-102)

@ Prodi Manajemen Fakultas Ekonomi Universitas Pamulang

Email: abdimasjurnal.unpam@gmail.com Telp: (021) 741-2566

more clearly about social media and how social media was used, but after the implementation of the PKM activity it was introduced that parents were expected to have more provisions and could be adjusted in the morning. PKM activities play a positive role in increasing knowledge and hope will benefit social media for the community to socialize and develop thinking of parents and children.

\section{Keywords: PKM, Social Media, Thinking Development, Parents and Children}

\section{PENDAHULUAN}

Pada masa sekarang ini, sebagian besar tentunya setiap orang memiliki akun media sosial. Dahulu mungkin kita pernah mengenal Friendster atau Facebook saja, namun saat ini, sudah banyak sekali pilihan media sosial dengan fungsi yang berbeda-beda. Ada yang tempat berbagi video seperti Youtube, berbagi gambar seperti Instagram, tempat chatting seperti Whatsapp, berbagi tulisan di micro blog seperti Twitter dan masih banyak lagi.

Dengan menjamurnya media sosial saat ini, berdampak semakin mudahnya setiap orang untuk mendapatkan dan membagikan informasi dengan cepat dan murah. Karena memang salah satu fungsi media sosial adalah mempermudah kegiatan manusia sehari-hari. Beberapa manfaat positif media sosial bagi masyarakat, media sosial bermanfaat dan berperan untuk menghimpun keluarga, mempertemukan kembali keluarga yang sudah lama tidak bertemu. Sebagai media penyebaran informasi yang up to date, informasi sangat mudah menyebar melalui situs media sosial, hanya dalam tempo beberapa menit setelah kejadian, maka kita telah dapat menikmati informasi tersebut. Berkembangnya kemungkinan untuk bersosialisasi, komunikasi dan pertemanan yang tidak saja lintas propinsi, tetapi juga bisa lintas negara. Membuka kesempatan untuk proses belajar, di dalam media sosial kita bisa mendapatkan berbagai macam ilmu dan pengetahuan.

Namun ternyata, kemudahankemudahan yang ditawarkan dari perkembangan teknologi komunikasi, selain membawa dampak positif juga membawa pengaruh negatif terhadap waktu bermain dan belajar anak. Diantaranya, akses tanpa batas terhadap tayangan yang berbau kekerasan dan pornografi selain itu juga dapat memicu perilaku konsumtif untuk membeli benda yang di iklankan di internet. Anak-anak mempunyai perilaku yang cenderung meniru hingga mencoba yang dianggap baru dan menantang Kecanduan menggunakan media sosial terjadi di berbagai kalangan usia, tak hanya kaum muda dan remaja saja, melainkan anak-anak hingga orang tua saat ini juga ketagihan menggunakan media sosial.

Pemerataan ini mungkin dikarenakan penggunaan ponsel dan internet bukan sesuatu yang sulit lagi ditemukan. Berbeda dengan dahuulu, gadget dan internet adalah barang yang hanya digunakan pada kalangan tertentu saja. Pentingnya memahami dan menyadari bagaimana penggunaan media sosial yang baik dan benar dirasa perlu dilakukan baik diri sendiri 


\section{JURNAL ABDIMAS

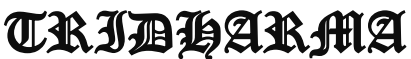

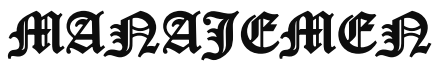

sebagai individu pengguna maupun sebagai orang tua. Karena tanpa disadari masih banyak di lingkungan sekitar kita didapati anak-anak usia dini yang justru mendapatkan dan menggunakan media sosial yang dapat diakses tanpa batasan tersebut yang diperoleh dari orang tua mereka.

\section{Berdasarkan fenomena} tersebut, kami para Dosen Universitas Pamulang dari Prodi Manajemen dan mahasiswa mengadakan Pengabdian Kepada Masyarakat (PKM) bersama dengan para ibu-ibu Majlis Taklim Al Auladiyah, Bakti Jaya, Setu, Tangerang Selatan untuk memberikan pengarahan terkait sosial media dengan tema "Pengarahan serta Pengimplementasian Fungsi dan Pengaruh Media Sosial bagi Perkembangan Berfikir Orang tua dan Anak".

\section{RUMUSAN MASALAH}

Berdasarkan latar belakang masalah yang sudah dipaparkan di atas bahwa dibutuhkan pengarahan serta pengimplementasian fungsi dan pengaruh media sosial bagi perkembangan berfikir orang tua dan anak. Oleh karena itu kami merumuskan masalah dalam pengabdian masyarakat ini yaitu:

1. Bagaimana memberikan pemahaman tentang sosial media kepada Ibuibu Majlis Taklim Al Auladiyah?

2. Bagaimana memberikan pengetahuan tentang penggunaan sosial media yang baik kepada IbuIbu Majlis Taklim Al-Auladiyah?

3. Bagaimana memberikan pengarahanakan dampak baik dan buruknya sosial media kepada Ibuibu Majlis Taklim Al Auladiyah?

4. Bagaimana memberikan pengimplementasian tentang Sosial media yang baik dan bermanfaat kepada Ibu-ibu Majlis Taklim Al Auladiyah?

\section{TUJUAN PELAKSANAAN}

1. Memberikan pemahaman tentang sosial media kepada kepada Ibu-ibu Majlis Taklim Al Auladiyah.

2. Memberikan pengetahuan tentang kegunaan sosial media yang baik kepada Ibu-ibu Majlis Taklim Al Auladiyah.

3. Memberikan pengarahan akan dampak baik dan buruknya penggunaan sosial media kepada Ibu-ibu Majlis Taklim Al Auladiyah.

4. Memberikan pengimplementasian tentang Sosial media yang baik dan bermanfaat berkepada Ibu-ibu Majlis Taklim Al Auladiyah.

\section{MANFAAT PELAKSANAAN}

1. Semua peserta kegiatan Pengabdian Kepada Masyarat mendapatkan ilmu baru dan wawasan terkait media sosial

2. Semua peserta kegiatan Pengabdian Kepada Masyarat mendapatkan pengarahan terkait penggunaan media sosial

3. Semua peserta kegiatan Pengabdian Kepada Masyarat mendapatkan pengetahuan akan pengimplementasian media sosial dalam kehidupan sehari-hari. 


\section{JURNAL ABDIMAS

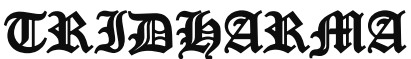

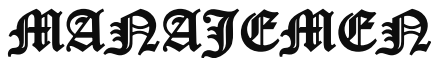

P-ISSN 2615-6849, E-ISSN 2622-3686

Jurnal ABDIMAS Vol. 1,No. 3,September 2020,Hal (95-102)

@ Prodi Manajemen Fakultas Ekonomi Universitas Pamulang

Email: abdimasjurnal.unpam@ gmail.com Telp: (021) 741-2566

\section{TINJAUAN PUSTAKA}

\section{Pengertian Media Sosial}

Media sosial (social media), seperti sudah biasa kita ketahui, termasuk golongan media yang terus menanjak popularitasnya. Jika melihat dari trend pencarian di Googlepada 10 tahun terakhir, volume pencarian frasa "social media" terus meningkat sejak 2008, sementara khusus versi Bahasa Indonesia (media sosial) terus menanjak sejak tahun 2012.

Pengertian media sosial menurut Philip Kotler dan Kevin Lane Keller (2016), adalah Media yang digunakan oleh konsumen untuk berbasis teks, gambar, suara dan video informasi baik dengan orang lain maupun perusahaan dan sebaliknya. Menurut Margie Clayman (2013), media sosial adalah alat pemasaran baru yang memungkinkan untuk mengetahui pelanggan dan calon pelanggan yang sebelumnya tidak mungkin.

Sedangkan menurut Dave Kerpen (2011), media sosial adalah teks, gambar, video dan kaitan secara daring yang dibagikan antara orangorang dan organisasi. Media sosial adalah sebuah istilah yang menggambarkan bermacam-macam teknologi yang digunakan untuk mengikat orang-orang kedalam suatu kolaborasi, saling bertukar informasi, dan berinteraksi melalui isi pesan berbasis web (Michael Cross, 2013). Dikarenakan internet selalu mengalami perkembangan, maka berbagai macam teknologi dan fitur yang tersedia bagi pengguna pun selalu mengalami perubahan. Hal ini menjadikan media sosial hypernym dibandingkan dengan sebuah referensi khusus terhadap berbagai pengunaan atau rancangan.

\section{Pengertian Pola Berfikir}

Dijelaskan oleh Carol S. Dweck yang namanya tidak asing lagi di bidang psikologi yang membahas tentang mindset dan Kata Growth dikutip dari kamus lengkap inggrisindonesia berarti pertumbuhan, perkembangan manakala, kata mindset terdiri dari dua kata, Mind dan Set. Kata "mind" berarti "sumber pikiran atau memori yaitu pusat kesedaran yang menghasilkan pemikiran, perasaan, ide, persepsi yang menyimpan pengetahuan dan memori. Kata "Set" berarti "mendahulukan peningkatan kemampuan dalam sesuatu kegiatan atau dalam keadaan yang utuh".

Pengertian pola berfikir menurut Mulyadi (2007), merupakan sikap mental mapan yang dibentuk melalui pendidikan, pengalaman dan prasangka. Lebih jauh lagi dapat dikatakan bahwa pola pikir adalah salah satu aspek perkembangan anak (peserta didik) yang berkaitan dengan pengertian (pengetahuan), yaitu semua proses psikologis yang berkaitan dengan bagaimana individu mempelajari dan memikirkan lingkungannya (Desmita, 2012).

Pola pikir merupakan hal yang penting untuk menjelaskan penilaian manusia dan pengambilan keputusan yang dalam beberapa keputusan dapat memperbaiki atau memperburuk bias keputusan (Hamilton, Vohs, Sellier, \& Meyvis, 2011). Definisi lain darimindset atau pola pikir menurut Satria (2015) adalah sekumpulan 


\section{JURNAL ABDIMAS

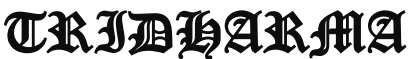

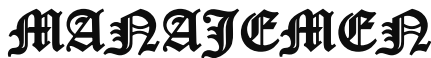

pikiran yang menjadi berkali-kali di berbagai tempat dan waktu, serta diperkuat dengan keyakinan dan proyeksi, sehingga menjadi kenyataan yang dapat dipastikan di setiap tempat dan waktu yang sama.

\section{METODE PELAKSANAAN}

1. Memberikan pemahaman tentang sosial media kepada kepada Ibu-ibu Majlis Taklim Al Auladiyah.

2. Memberikan pengetahuan tentang kegunaan sosial media yang baik kepada Ibu-ibu Majlis Taklim Al Auladiyah.

3. Memberikan pengarahan akan dampak baik dan buruknya penggunaan sosial media kepada Ibu-ibu Majlis Taklim Al Auladiyah.

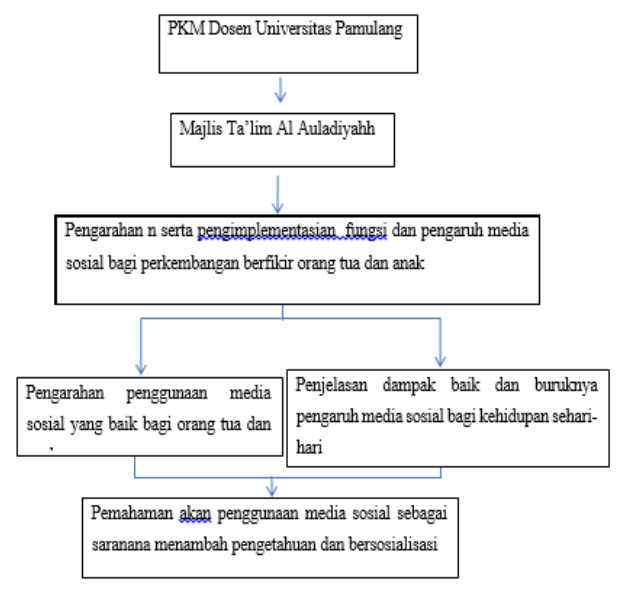

\section{HASIL DAN PEMBAHASAN}

Setelah dilaksanakan Pengarahan serta pengimplementasian media sosial, maka tingkat keberhasilan penyelenggaraan kegiatan Pengabdian Kepada Masyarakat ini dapat dilihat dari hasil evaluasi selama pelaksanaan kegiatan, yaitu:
1. Evaluasi proses yaitu untuk mengetahui pelaksanaan dari program yang dibuat serta keterlibatan peserta atau khalayak sasaran antara strategis selama mengikuti kegiatan. Evaluasi ini dilakukan dari awal sampai akhir kegiatan dengan melihat tanggapan peserta penjelasan dan contohcontoh yang diberikan, melakukan sesi tanya jawab yang interkatif namun hanya ada beberapa ibu-ibu yang belum bisa menangkap materi dengan baik dikarenakan usia.

2. Evaluasi hasil yaitu untuk mengetahui seberapa jauh tingkat keberhasilan tujuan yang telah dirumuskan, dapat dilihat dari respon (tanggapan) peserta terhadap sosialisasi pelatihan yang telah dilakukan pada saat kegiatan berlangsung.

Pelatihan dilakukan selama tiga hari pada tanggal 01 s/d 03 Juli 2020 dihadiri perserta Majlis Taklim sebanyak 30 peserta. Semua peserta mengikuti kegiatan secara penuh dikarenakan semua peserta antusias mengikuti kegiatan pengarahan dan pengimplentasian. Dari respon (tanggapan peserta) yang diberikan

Mereka semua sangat berharap kegiatan Pengabdian Kepada Masyarakat seperti ini dalam dilakukan kembali pada periodeperiode berikutnya. Adapun beberapa

faktor pendorong terlaksananya kegiatan pelatihan ini adalah sebagai berikut:

1. Dari pihak peserta (para ibu-ibu majlis taklim) begitu antusias dalam mengikuti seluruh rangkaian kegiatan pengabdian pada masyarakat ini. 


\section{JURNAL ABDIMAS

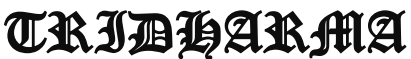

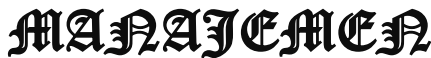

P-ISSN 2615-6849, E-ISSN 2622-3686

Jurnal ABDIMAS Vol. 1,No. 3,September 2020,Hal (95-102)

@ Prodi Manajemen Fakultas Ekonomi Universitas Pamulang

Email: abdimasjurnal.unpam@ gmail.com Telp: (021) 741-2566
2. Pelaksanaan kegiatan ini dapat memberikan pengetahuan tambahan/menambah wawasan bagi peserta mengenai pemanfaatan dan penggunaan media sosial uang baik.

3. Kesiapan dan semangat para peserta kegiatan ini begitu besar untuk mendapatkan pengetahuan yang disiapkan oleh panitia pelaksana.

4. Faktor pendorong lainnya adalah kesiapan anggota tim pelaksana yang telah menyiapkan diri, terutama dalam pemberi materi pada kegiatan pengabdian ini sangatlah interaktif dan memberikan suasana yang bersahaja.

\section{KESIMPULAN DAN SARAN}

\section{KESIMPULAN}

Pelaksanaan

kegiatan pengabdian kepada masyarakat oleh Lembaga Penelitian dan Pengabdian Masyarakat (LPPM) Universitas Pamulang yang dilakukan oleh dosendosen Universitas pada program studi manajemen telah berjalan dengan lancar dan mendapat sambutan hangat dari tempat pelaksanaan kegiatan ini yaitu Majilis Taklim pada Masjid Al Auladiyah, Bakti Jaya, Tangerang Selatan.

Harapan kami selaku dosen, dengan pengabdian ini dapat menambah pemahaman dan wawasan tentang penggunaan sosial media yang sangatlah memberikan pengaruh penting bagi perkembangan berfikir orang tua dan anak.

Materi yang kami berikan yaitu tentang gambaran secara umum terkait sosial media, pengarahan penggunaan sosial media, dampak baik dan buruknya sosial media bagi orang tua dan anak dan segala batasan yang harus dilakukan pada penggunaan sosial media dan juga masukan bagi para ibu-ibu majlis taklim tersebut untuk dapat mengimplementasikannya dalam kehidupan sehari-hari, sehingga dapat membantu dan meningkatkan tingkat pengetahuan sosial dan kepribadian yang sehat dan bermanfat dalam kehidupan mereka pada masa yang akan datang.

\section{SARAN}

Dalam laporan kegiatan ini mungkin banyak kekurangan yang ada, untuk itu kami berharap masukan dan kritikan dalam rangka perbaikan untuk kegiatan-kegiatan pengabdian masyarakat di masa yang akan datang. Semoga kegiatan pengabdian masyarakat ini dapat bermanfaat bagi masyarakat sekitar Universitas Pamulang.

Akhirnya, kami mengucapkan terima kasih kepada seluruh pihak yang telah mendukung kegiatan yang kami laksanakan dan kami mohon maaf apabila dalam laporan ini banyak ditemukan kekurangan.

\section{DAFTAR PUSTAKA}

Cahyo, Satria, You Are What You Think You Are What You Believe, Yogyakarta: Shira Media, 2015.

Clayman, Margie, 17 Maret 2013, "Defining Social Media Friendships", (Online).

(margieclayman.com/defining-socialmedia-friendshipsdiakses 22 Juli 2020). 


\section{JURNAL ABDIMAS

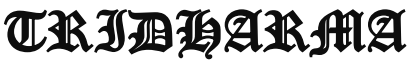

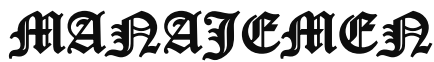

P-ISSN 2615-6849, E-ISSN 2622-3686

Jurnal ABDIMAS Vol. 1,No. 3,September 2020,Hal (95-102)

@ Prodi Manajemen Fakultas Ekonomi Universitas Pamulang

Email: abdimasjurnal.unpam@ gmail.com Telp: (021) 741-2566
Cross, Michael, Social Media Security $1^{\text {st }}$ Edition Leveraging Social Networking While Mitigating Risk, Syngress, 2013.

Desmita, Psikologi Perkembangan Peserta Didik, Bandung: Remaja Rosdakarya, 2012.

https://uzone.id/bagaimana-mediasosial-bisa-mengubah-pola-pikir-orang (dikutip tanggal 25 Juli 2020, pukul 14.00)

Kementrian Perdagangan RI,(Jakarta : Pusat Humas Kementerian Perdagangan RI, 2014).

Kerpen, Dave, Likeable Social Media. United States: Mc Graw Hill, 2011.

Kotler, Philip, Kevin Lane Keller, Marketing Management,14th Edition. United States of America : Pearson, 2012.

\section{Majalah Business Horizons (2010)}

Mulyadi, Seto, Home Schooling Keluarga Kak Seto, Bandung: Kaifa, 2007.

Pasaribu, V. L. D., Susanti, F., \& Hartuti, E. T. K. (2019). Memotivasi Siswa dan Siswi SMK Letris Indonesia di Dalam Menentukan Pilihan Untuk Melanjutkan Pendidikan Atau Bekerja Setelah Lulus Sekolah. Jurnal Pengabdian Dharma Laksana, 1(2), 161-172.

Pasaribu, V. L. D., Agrasadya, A., Shabrina, N., \& Krisnaldy, K. (2020). MENJADI ENTERPRENEUR MUDA YANG MEMILIKI JIWA LEADERSHIP UNTUK MENGHADAPI MASA DEPAN. Abdi Laksana, 1(1).

Pasaribu, V. L. D., Elburdah, R. P., Sudarso, E., \& Fauziah, G. (2020). PENGGUNAAN MANAJEMEN WAKTU TERHADAP PENINGKATAN PRESTASI BELAJAR DI SMP ARAISIYAH. Jurnal ABDIMAS Tri Dharma Manajemen, 1(1).
Pasaribu, V. L. D., Sulaiman, S., Sutiman, S., Thaharudin, T., \& Purnomo, B. Y. (2020). PENGENALAN LETAK POSYANDU TERDEKAT DIKELURAHAN PISANGAN DENGAN MANAJEMEN PEMASARAN REVOLUSI 4.0 UNTUK MENINGKATKAN PENGETAHUAN MASYARAKAT LETAK DAN FUNGSI POSYANDU TERDEKAT PADA KELURAHAN

PISANGAN. DEDIKASI PKM, 1(1), 105-110.

Pasaribu, V. L. D., Oktrima, B., Prabowo, B., Arianto, N., \& Haryoko, U. B. (2020). PROGAM PENDAMPINGAN DAN PENYELENGGARAAN PENDIDIKAN ANAK PADA USIA DINI TERHADAP PRESTASI BELAJAR DILINGKUNGAN RT 020 RW 009. KEL GIRI PENI. KEC WATES. YOGYAKARTA. JURNAL LOKABMAS KREATIF, I(1), 71-75

R. Hamilton, K. D. Vohs, A.-L. Sellier, and T. Meyvis, "Being of Two Minds: Switching Mindsets Exhausts SelfRegulatory Resources," Organ. Behav.

Hum. Decis. Process., pp. 13-24, 2011. www.gurupendidikan.co.id

\section{DOKUMENTASI}

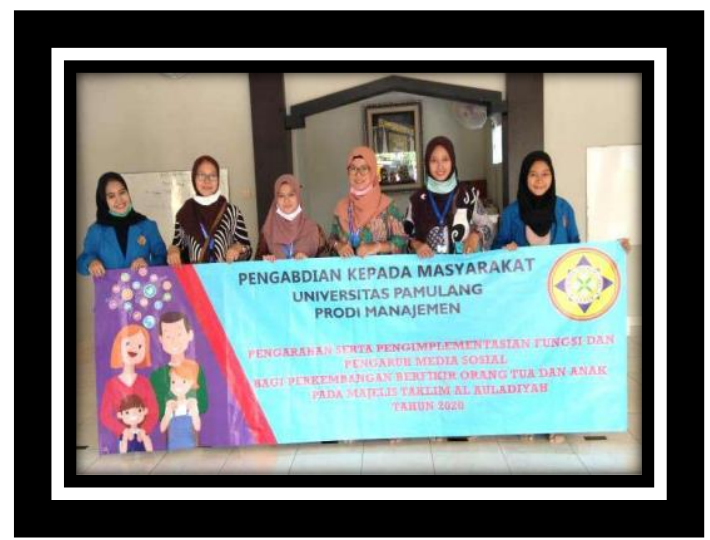


JURNAL ABDIMAS

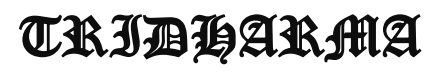

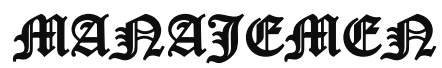

P-ISSN 2615-6849, E-ISSN 2622-3686

Jurnal ABDIMAS Vol. 1,No. 3,September 2020,Hal (95-102)

@ Prodi Manajemen Fakultas Ekonomi Universitas Pamulang

Email: abdimasjurnal.unpam @ gmail.com Telp: (021) 741-2566
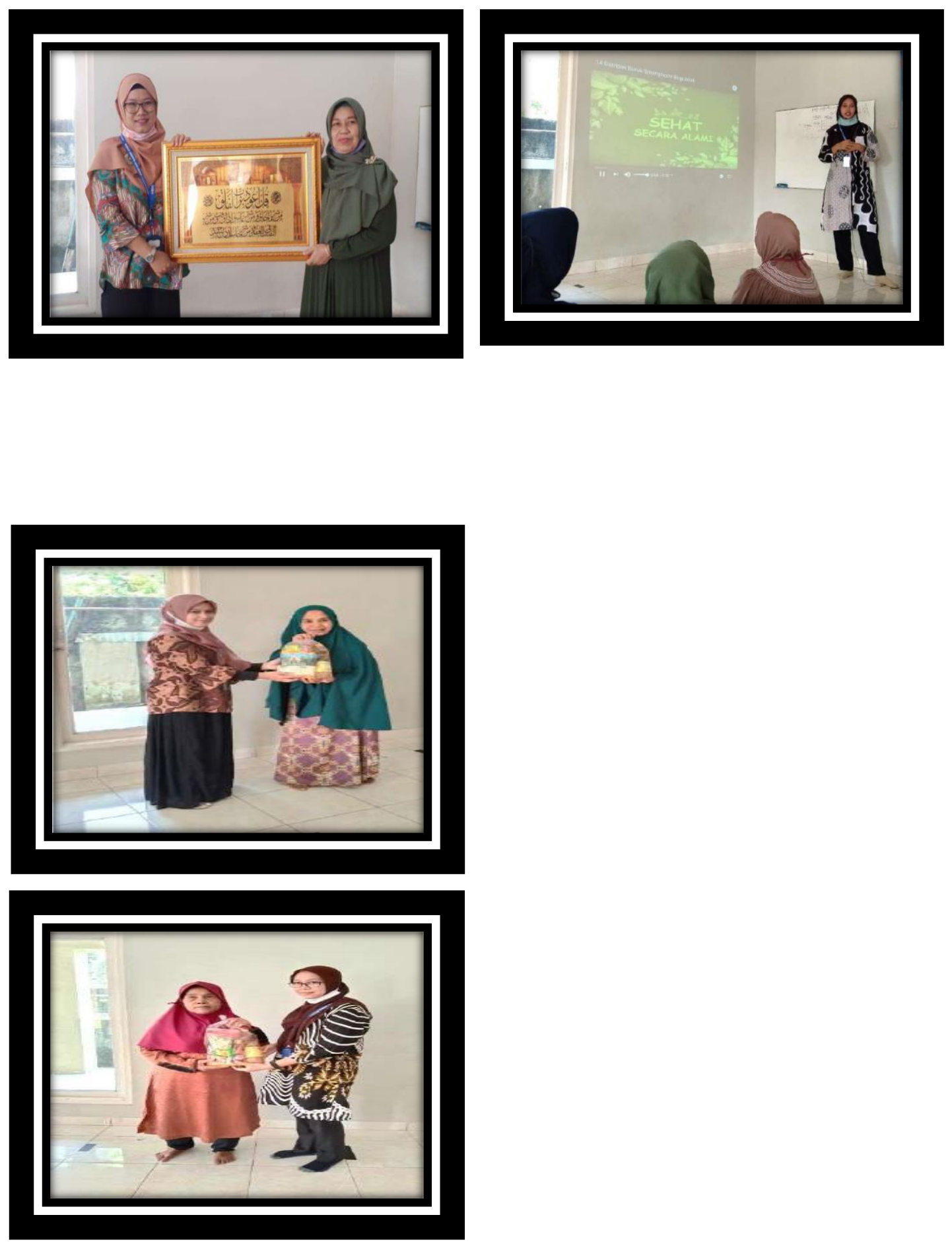